\title{
ЗАСТОСУВАННЯ СУЧАСНИХ ПЕДАГОГІЧНИХ ТЕХНОЛОГІЙ ДЛЯ ПІДВИЩЕННЯ ЯКОСТІ ПІДГОТОВКИ ЛІКАРІВ У ДОНЕЦЬКОМУ НАЦІОНАЛЬНОМУ МЕДИЧНОМУ УНІВЕРСИТЕТІ іМ. М. ГОРЬКОГО
}

\author{
Ю. В. Думанський, Б. Б. Івнєв, М. Б. Первак, Р. В. Басій, А. В. Владзимирський \\ Донецький національниймедичний університет імені М. Горького

\section{USING CONTEMPORARY PEDAGOGICAL TECHNOLOGIES FOR IMPROVEMENT OF DOCTORS' TRAINING QUALITY IN DONETSK NATIONAL MEDICAL UNIVERSITY BY M. HORKYI}

\author{
Yu. V. Dumanskyi, B. B. Ivnyev, M. B. Pervak, R. V. Basiy, A. V. Vladzymyrsky \\ Donetsk National Medical University by M. Horkyi
}

\begin{abstract}
У статті висвітлено досвід Донецького національного медичного університету ім. М. Горького із впровадження інтерактивних методів та дистанційного навчання для підвищення якості підготовки лікарів на до- та післядипломному рівнях медичної освіти.
\end{abstract}

The article deals with the experience of Donetsk National Medical University by M. Horkyi in implementation of interactive methods and distance learning for improving doctors' training quality at undergraduate and postgraduate levels of medical education.

Вступ. Головною метою реформування вітчизняної системи медичної освіти є підвищення рівня підготовки лікарів - як на додипломному, так і на післядипломному етапах. Реалізація цієї мети потребує не лише постійного оновлення змісту навчання відповідно до новітніх досягнень медичної науки та практики, розробки та впровадження нового покоління галузевих стандартів освіти, значного поліпшення матеріально-технічного забезпечення медичних ВНЗ, використання адекватного методичного забезпечення навчального процесу, але й застосування сучасних підходів до організації навчання.

Основна частина. На думку європейських експертів у галузі освіти $[1,2,11]$, одним з основних чинників забезпечення якості підготовки фахівців є заміна старої освітньої парадигми з викладачем у центрі на так званий студентоцентрований підхід. Останній відповідає положенням педагогічної психології про те, що навчити можна лише особу, яка хоче навчатися, і у якої сформовано таку важливу універсальну компетенцію, як “здатність вчитися” [4, 5].

Аналогічний підхід було застосовано при розробці та впровадженні у Донецькому національному медичному університеті ім. М. Горького (ДонНМУ) оригінальної системи управління якістю підготовки

( Ю. В. Думанський, Б. Б. Івнєв, М. Б. Первак та ін. лікарів [6, 7, 8]. Крім орієнтації всього навчального процесу на кінцеві цілі (освоєння професійних компетенцій), було відібрано оптимальні форми навчальних занять та методи навчання. Згідно з прийнятими у ДонНМУ стандартами, лекції мають бути переважно проблемними, щоб не лише надати студентам певну інформацію, але й сприяти в них розвитку клінічного мислення, здатності розв'язання проблем, створювати мотивацію до постійного самостійного пошуку необхідної медичної інформації. Відповідно до затверджених у ДонНМУ структур проведення практичних занять на медичних та стоматологічному факультетах, близько 70 \% загального часу відведено на самостійну роботу студентів під керівництвом викладача та наступний аналіз їі результатів.

На жаль, на початку 2000-х років у ДонНМУ, як і в інших медичних ВНЗ країни, збільшилась питома вага теоретичної складової навчання. Це обумовлене цілою низкою різних чинників, серед яких не лише гонитва за кращими результатами ліцензійних тестових іспитів, але й об'єктивні обставини: недостатнє фінансування ВНЗ для забезпечення навчання малими групами, проблеми з виробничою практикою, що виникли останніми роками, неврегульованість правових аспектів залучення пацієнтів до навчального процесу, інколи відсутність тематичних хворих тощо. 
Для поліпшення ситуації у 2010-2013 рр. у ДонНМУ було розроблено та проведено комплекс заходів, спрямованих на підвищення практичної підготовки студентів. Додатковим суттєвим чинником позитивного впливу, на нашу думку, має бути "реанімація" так званих активних методів навчання, поширення інтерактивних освітніх технологій та впровадження елементів дистанційної освіти $[3,9,10]$.

Починаючи 32011 р., нами було проведено відповідні пілотні проекти. Насамперед, співробітниками методичних підрозділів ДонНМУ було підготовлено огляди про застосування інтерактивних методів навчання у вітчизняних та закордонних ВНЗ при підготовці лікарів. На підставі цих матеріалів головами методичних комісій було розроблено змістовні методичні рекомендації з оптимального використання цієї педагогічної технології на кафедрах відповідного профілю. Ці рекомендації було обговорено з доцентами кафедр на спеціальних семінарах-тренінгах.

Враховуючи виражену специфіку навчального процесу при викладанні різних дисциплін, а також різні рівні викладання, для пілотного проекту було відібрано 6 кафедр:

-1 кафедра гуманітарного профілю (іноземних та латинської мов);

-2 кафедри медико-біологічного профілю (хімії, а також гістології, цитології та ембріології);

-1 випускаюча кафедра гігієнічного профілю (соціальної медицини, організації охорони здоров'я та історії медицини);

-2 випускаючі клінічні кафедри (внутрішньої медицини та педіатріі).

Основним завданням, поставленим перед цими кафедрами, було підготувати і провести відкриті навчальні заняття із застосуванням інтерактивних методів навчання, причому в більшості випадків - інтерактивних за суттю, без використання спеціальних технічних засобів.

Як показали результати пілотного проекту, на практичних заняттях найчастіше застосовувалися такі інтерактивні методи, як “мозковий штурм", "робота в малих групах", “метод дискусії, “кейс-метод”, заняття-конференція, ділова та рольова гра. Щодо лекцій, то, як правило, це були проблемні лекції, лекція-візуалізація, лекція-дискусія.

У всіх випадках викладач виступав у ролі організатора процесу навчання і забезпечував умови для ініціативи студентів, причому до активної пізнавальної діяльності були залучені всі ті, хто навчається.

Наприкінці лекцій визначали задоволеність студентів інтерактивною формою навчання, а на практичних заняттях, крім того, ще й оцінювали ефективність засвоєння студентами знань при новому підході (на підставі результатів вихідного і кінцевого тестування). У подальшому отриману величину порівнювали 3 ефективністю вивчення студентами цієї групи іншої теми - аналогічної за складністю та обсягом навчальної інформації, але вивченоюбезпедагогічних інновацій.

Виявилося, що при використанні інтерактивних методів задоволеність студентів такою формою заняття становила 93-100 \%, тоді як при традиційній формі цей показник не перевищував $73 \%$. Відзначено підвищення ефективності засвоєння знань при інтерактивній формі навчання на 7-10\%.

Було відібрано оптимальні інтерактивні методи для навчання студентів на різних кафедрах:

- кафедри медико-біологічного профілю: “мозковий штурм”, "робота в малих групах", “метод дискусії”, "кейс - метод";

- кафедри гуманітарного профілю - заняття-конференція, рольова гра;

- випускаючі кафедри гігієнічного та клінічного профілю, а також кафедри післядипломного навчання - ділова гра, “кейс-метод”.

Аналіз результатів пілотного проекту показав ряд переваг інтерактивних методів навчання порівняно 3 традиційними:

1) підвищують ступінь задоволеності студентів освітнім процесом;

2) збільшують ефективність навчання;

3) дозволяють студентам відпрацювати навички роботи з інформаційними джерелами;

4) прищеплюють студентам навички колективної роботи (багатосторонньої комунікації);

5) забезпечують безперервний діалог викладача i студентів у вирішенні сформульованих завдань.

Ще одним важливим висновком пілотного проекту стала доведеність тісного зв'язку між ефективністю застосування інтерактивних методів навчання та рівнем організаційної та методичної підготовки такого заняття. Зважаючи на цей факт, ми поступово розширювали перелік кафедр, на яких використовується ця сучасна педагогічна технологія. У поточному семестрі заплановано понад 150 інтерактивних практичних занять та лекцій на майже 30 кафедрах, у тому числі на 4 кафедрах навчально-наукового інституту післядипломної освіти.

Водночас, починаючи з 2011 року, ми проводили системне впровадження дистанційного навчання, основними завданнями якого було:

- розширення можливостей доступу різних категорій тих, хто навчається, до якісного навчання; 
- збільшення кількості фахівців, що проходять навчання за програмами післядипломної освіти, при зменшенні витрат на навчання, проїзд і проживання;

- індивідуалізація процесу навчання відповідно до потреб, особливостей і можливостей слухачів;

- підвищення ефективності навчання слухачів шляхом застосування сучасних психолого-педагогічних та інформаційно-комунікаційних технологій;

- забезпечення контролю якості освіти.

Наразі у ДонНМУ дистанційне навчання здійснюється як складова частина додипломної освіти, а також у системі післядипломної освіти для перепідготовки, спеціалізації та підвищення кваліфікації фахівців.

Припідготовці до впровадження дистанційного навчання (ДН) нами було визначено такі стратегічні етапи:

1. Попереднє тестово-апробаційне застосування ДН.

2. Підготовка та затвердження нормативної та методичної бази ДН.

3. Системотехнічна реалізація та підготовка користувачів.

4. Пілотне впровадження, аналіз результатів та корекція загальної стратегії.

5. Широке впровадження на до- та післядипломному рівнях.

На першому етапі нами використано окремі технології ДН (веб-середовища різних виробників та такі, що мають відкритий код, апаратні та програмні відеоконференції, рішення для вебінарів тощо). В процесі здійснення курсів тематичного удосконалення з різних аспектів організації охорони здоров'я окремі теми надавались за дистанційною формою. Нами проводилась оцінка якості, зручності, функціональності різних телекомунікаційних інструментів, у тому числі з урахуванням фінансових аспектів. Особливу увагу ми приділяли доступності засобів ДН для широкого кола користувачів. Треба особливо підкреслити, що на етапі тестово-апробаційного застосування нами було підготовлено та проведено повністю англомовний 36-годинний курс дистанційного навчання 3 телемедицини та електронної охорони здоров'я на замовлення New Bulgarian University (Софія, Болгарія). На курсі пройшли навчання близько 70 студентів кількох курсів з вищезгаданого вузу. Під час проведення курсу нами остаточно визначено пріоритети для системотехнічних рішень.

На другому етапі нами було проведено ретельний аналіз нормативної та методичної документації з ДН в Україні. На основі чинних законодавчих документів нами було розроблено та затверджено: Положення про дистанційне навчання у Донецькому національному медичному університеті ім. М. Горького; Положення про створення, оновлення, використання, захист і зберігання веб-ресурсів навчальної програми зі спеціальності та дисципліни; Положення про науково-методичну експертизу та сертифікацію веб-ресурсів навчальної програми зі спеціальності та дисципліни.

Сумісно з відповідними фахівцями було встановлено порядок обліку методичної та навчальної роботи педагогічних та науково-педагогічних працівників ДонНМУ при організації навчального процесу за технологіями дистанційного навчання. Розроблено форму інформованої згоди на участь у курсі дистанційного навчання, яку обов' язково підписують усі учасники, що навчаються.

Нами постійно здійснюється моніторинг законодавчої бази ДН в Україні, і відповідно до нових документів, вимог, рекомендацій ми вносимо корективи до внутрішньоуніверситетських нормативів.

Для системотехнічної реалізації ДН нами було обрано такі складові: окремий сервер з мережевим обладнанням та швидкісним підключенням до Інтернет; веб-середовище Moodle; SCORM-конвертор iSpring; програмну систему відеоконференц-зв'язку eWorks.

Таким чином, ми застосовуємо систему управління веб-ресурсами навчальної програми зі спеціальності та дисципліни на основі платформи Moodle (www.moodle.org, розповсюджується 3 відкритим кодом). Основними перевагами цього рішення є:

-індивідуалізація інсталяції;

- зручність та гнучкість;

- можливість реалізації будь-якого педагогічного сценарію;

- можливість створення власних додатків та модулів для платформи;

- позитивний досвід застосування в тисячах вузів

у глобальному масштабі;

- фінансова доступність;

- позитивний досвід застосування, отриманий власноруч на етапі тестово-апробаційного застосування ДН.

Для здійснення відеоконференції нами обрано програмне рішення eWorks (www.e-works.com). Основними перевагами цього рішення $\epsilon$ :

- desk-top'не індивідуальне рішення;

- гнучкість у відповіді до апартної бази та швидкості каналів зв' язку;

- зручність та доступність для користувачів;

- можливість проведення багатоточкових сеансів;

- зручна сумісна робота з навчальним контентом, підключення до зовнішніх веб-ресурсів;

- підтримка сумісної роботи 3 контентом в стандарті DICOM (вкрай важлива функція з погляду медичної освіти); 
- фінансова доступність;

- позитивний досвід застосування, отриманий власноруч на етапі тестово-апробаційного застосування ДН.

Функціонально засоби дистанційного навчання об' $є$ днано на освітньому порталі ДонНМУ - https:// sdo.dnmu.edu.ua.

У процесі системотехнічної реалізації нами було проведено етапні тренінги та інструктажі співробітників університету. В 2013 році нами проведено пілотне впровадження ДН на післядипломному рівні. Було здійснено такі 72-годинні курси тематичного удосконалення: “Актуальні питання кардіологіі”; “Актуальні питання дитячої та підліткової дерматологіі”; “Електронний менеджмент (телемедицина та інші IT) в охороні здоров'я". Веб-ресурси відповідних курсів було розміщено на порталі https://sdo.dnmu.edu.ua

\section{Література}

1. Болонский процесс: поиск общности европейских систем высшего образования (проект TUNING) / под ред. В. И. Байденко.-Москва, 2006. -210 с.

2. Болонский процесс: результаты обучения и компетентностный подход/подред. В. И. Байденко.-Москва, 2009. - 536 с.

3. Думанський Ю. В. Електронна охорона здоров'я та телемедицина в післядипломній освіті-інновації Донецького національного медичного університету ім. М. Горького / Ю. В. Думанський, А. В. Владзимирський // Укр. ж. телемед. мед. телемат. -2012. - Т. 10, № 1.-С. 4-12.

4. Зимняя И. А. Педагогическая психология / И. А. Зимняя. - Москва : Логос, 2001. -383 с.

5. Методологія і технологія визначення універсальних компетенцій випускників медичних та стоматологічних факультетів / [Ю.В.Думанський, Б. Б. Івнєв, М.Б.Первак та ін.]. - Донецьк, 2013. -112 с.

6. Опыт управления учебной деятельностью студентов при реализации компетентностного подхода / [Ю.В.Ду- відповідно до педагогічного сценарію; за спеціальним розкладом здійснювались лекції у режимі відеоконференції. Усі слухачі успішно пройшли курси та отримали відповідні документи. Критичних технічних збоїв не зафіксовано, 90-95 \% слухачів та викладачів надали позитивну оцінку запровадженим технологіям ДН.

У 2014 р. ми перейшли до фази широкого впровадження дистанційного навчання на кафедрах післядипломної освіти, а також кафедрах, що навчають студентів фармацевтичного відділення із заочної формою навчання.

Висновок. Вважаємо, що впровадження у ДонНМУ інтерактивних методів та дистанційного навчання сприятиме подальшому підвищенню якості підготовки лікарів на до- та післядипломному рівнях.

манский, В. Н. Казаков, А. Н. Талалаенко и др.]. - Москва, 2010. -64 c.

7. Методологія і реалізація системи управління якістю медичної освіти / [В. М. Казаков, О. М. Талалаєнко, М. Г. Гаріна та ін.]. - Донецьк, 2001.-213 с.

8. Управление качеством подготовки специалистов: программно-целевой подход (на примере высшего и послевузовского медицинского образования) / [В. Н. Казаков, Н. А. Селезнева, А. Н. Талалаенко и др.]. -2-е изд. - Москва, 2007.-215 c.

9. Abstracts of Conference of Association for Medical Education in Europe. - Vienna, 2011. - 479 p.

10. Abstracts of Conference of Association for Medical Education in Europe. - Prague, 2013. - 536 p.

11. Dent J.A.A practical guide for medical teachers / J.A. Dent, R. M. Harden // Churchill Livingstone Elsevier: Edinburgh, London, New York, Oxgord, Philadelphia, St. Louis, Sydney, Toronto, 2009. $-435 \mathrm{p}$. 